\title{
FIRST REPORT OF Amaranthus viridis RESISTANCE TO HERBICIDES ${ }^{1}$
}

\author{
Primeiro Relato de Resistência de Amaranthus viridis a Herbicidas
}

\author{
FRANCISCHINI, A.C. ${ }^{2}$, CONSTANTIN, J. ${ }^{2}$, OLIVEIRA JR., R.S. ${ }^{2}$, SANTOS, G. ${ }^{2}$, BRAZ, G.B.P. ${ }^{2}$, and \\ DAN, H.A. ${ }^{3}$
}

\begin{abstract}
Due to the limited number of herbicides registered for the control of dicot weeds in cotton crops, ALS inhibitors have been used on an intensive and recurrent basis. Given that, cases of poor weed control have been described after application of these herbicides in the main cotton producing areas in Brazil, the purpose of the present work was to evaluate the occurrence of resistance to ALS herbicides in Amaranthus viridis biotypes from those areas. Dose-response curves were prepared after pre-emergence applications of trifloxysulfuron-sodium $\left(0 ; 1.8 ; 3.7 ; 7.5 ; 15\right.$ and $\left.30 \mathrm{~g} \mathrm{ha}^{-1}\right)$ and pyrithiobac-sodium $(0 ; 35 ; 70$; 140; 280 and $560 \mathrm{~g} \mathrm{ha}^{-1}$ ), equivalent to $0,1 / 4,1 / 2,1,2$ and 4 times the recommended commercial rates. The selection of trifloxysulfuron-sodium resistant biotypes of $A$. viridis was confirmed in samples from Bahia (BA 7, BA 8, BA 9 and BA 11). However, no resistance to pyrithiobacsodium was found for biotypes either from Bahia or from Mato Grosso do Sul.
\end{abstract}

Keywords: trifloxysulfuron-sodium, pyrithiobac-sodium, slender amaranth, ALS-inhibiting herbicides.

\begin{abstract}
RESUMO - Devido ao limitado número de herbicidas registrados para o controle de dicotiledôneas no cultivo do algodoeiro, herbicidas inibidores da ALS tem sido utilizados de forma intensiva $e$ recorrente. Em função de falhas de controle observadas com estes produtos nas principais áreas de produção desta cultura no Brasil, o presente trabalho teve por objetivo identificar a possivel ocorrência de resistência a estes herbicidas em biótipos de Amaranthus viridis provenientes destas áreas. Foram elaboradas curvas de dose-resposta após aplicações em pré-emergência dos herbicidas trifloxysulfuron-sodium (0,0; 1,8; 3,7; 7,5; 15,0 e 30,0 $\left.\mathrm{g} \mathrm{ha}^{-1}\right)$ e pyrithiobac-sodium (0,0; 35, 0; 70,0; 140, 0; 280, 0 e 560, O $\mathrm{g} \mathrm{ha}^{-1}$ ), equivalentes a 0, 1/4, 1/2, 1, 2 e 4 vezes a dose comercial recomendada. Foi confirmada a seleção de biótipos de $\boldsymbol{A}$. viridis resistentes ao trifloxysulfuron-sodium provenientes de amostras coletadas no estado da Bahia (BA 7, BA 8, BA 9 e BA 11). No entanto, não foi confirmado nenhum caso de resistência ao pyrithiobac-sodium nos biótipos coletados nos estados do Mato Grosso do Sul e Bahia.
\end{abstract}

Palavras-chave: trifloxysulfuron-sodium, pyrithiobac-sodium, caruru-de-mancha, herbicidas inibidores da ALS.

\section{INTRODUCTION}

There are about 60 species of Amaranthus in the world, and at least 20 of them are recognized as weeds. In agricultural areas of Brazil, several species are considered to be problematic. The most widespread species are Amaranthus deflexus, Amaranthus hybridus,
Amaranthus lividus, Amaranthus retroflexus, Amaranthus viridis and Amaranthus spinosus (Carvalho et al., 2006; Raimondi et al., 2010). Species within this genus are among the three most problematic weeds of North American agriculture and between the two most problematic species in cotton crops in that country (Wise et al., 2009),

Recebido para publicação em 27.3.2014 e aprovado em 7.4.2014.

2 Universidade Estadual de Maringá, Maringá-PR, Brasil, <aleconstantin@agronoma.eng.br>; ${ }^{3}$ Instituto Federal de Educação Ciência e Tecnologia de Rondônia, Colorado do Oeste, Roraima-RO, Brasil. 
Slender amaranth (Amaranthus viridis) is a species native to the Caribbean, found in tropical and subtropical regions of the world, and known to infest more than 50 crops. It is present in arable fields in over 80 countries. It stands out for its adaptability to the environment and prolific seed production.

Present in producing fields across Brazil, A. viridis is widespread in crops, occurring in all regions of the country (Maluf, 1999; Lorenzi $\&$ Matos, 2002). Together with other species of the genus Amaranthus, they are considered the most abundant weeds of Brazil's south and center-west regions. They are found in wheat, corn, flax, grass, coffee, peanuts, soybeans, cotton, beans (Viana, 1982; Lorenzi \& Matos, 2002), as well as in areas of horticulture.

There are only 17 herbicides registered for the control of dicot weeds in cotton crops in Brazil. Only nine of them are registered for control of $A$. viridis. Many farmers have reported problems controlling A. viridis, especially in cotton, given the lack of registered herbicides, and also because it is difficult to identify this species in the field (Francischini, 2012).

Acetolactate synthase inhibiting (ALS) herbicides are often used as a result of the ease of use, broad spectrum of weed control, selectivity and optimal control they provide. In particular, trifloxysulfuron-sodium and pyrithiobac-sodium are applied sequentially in both pre and post-emergence at least two or three times during each growth cycle of cotton, because it is necessary to keep the crop free from weed throughout that period. The intensive use of these herbicides in major cotton growing areas in Brazil may have led to selection of resistant biotypes, which may be the cause of complaints of control failures recently observed in the field.

The objective of this study was to identify the presence of Amaranthus viridis biotypes that are resistant to ALS-inhibiting herbicides on cotton-producing fields in the states of Mato Grosso do Sul and Bahia.

\section{MATERIAL AND METHODS}

Seeds of Amaranthus viridis biotypes with suspected resistance were collected in March
2010 in cotton producing regions in Chapadão do Sul (Mato Grosso do Sul) and São Desidério (Bahia) that showed control failures for several consecutive harvests. The biotype considered to be susceptible (SB) was taken from an area in the state of São Paulo where herbicide had not been applied for more than five years (Table 1).

In areas where $A$. viridis biotypes were collected, there are records of applications of ALS-inhibiting herbicides in consecutive soybean, cotton and corn crops for more than 10 years.

At all stages, 50 seeds of each biotype were sown in pots with a capacity of $3 \mathrm{dm}^{3}$ of soil (experimental unit), placed superficially $(\sim 0.5 \mathrm{~cm})$, and applications of the herbicide treatments were performed shortly after weeds had been sown on moist soil using pressurized backpack sprayer with a constant pressure of $35 \mathrm{lb} \mathrm{pol}{ }^{-2}$, outfitted with three XR 11002 tips, spaced $0.5 \mathrm{~m}$ apart and placed at $0.5 \mathrm{~m}$ from the surface of the targets, providing a rate of $200 \mathrm{~L} \mathrm{ha}^{-1}$.

The soil samples used had a sandy loam texture, and were underwent analysis to determine chemical properties and grain size. The soil used in the experimental units had $\mathrm{pH}\left(\mathrm{H}_{2} \mathrm{O}\right) 5.50 ; 4.13 \mathrm{~g} \mathrm{dm}^{-3}$ of $\mathrm{C} ; 14 \%$ coarse sand; $38 \%$ fine sand; $6 \%$ silt and $42 \%$ clay.

Herbicides used for identification of suspected resistance were trifloxysulfuronsodium and pyrithiobac-sodium, applied in preemergence of Amaranthus viridis biotypes. These herbicides were chosen because of their recurrent use in cotton fields and because of their potential to control species of the genus

Table 1 - Geographical coordinates of the collection sites of seed samples of Amaranthus viridis

\begin{tabular}{|c|c|c|}
\hline Location & Sample & Coordinates \\
\hline Chapadão do Sul-MS & MS 1 & $18^{\circ} 40^{\prime} 41.94^{\prime \prime} \mathrm{S} / 52^{\circ} 53^{\prime} 58.90^{\prime \prime O}$ \\
\hline São Desidério-BA & BA 7 & $12^{\circ} 41^{\prime} 41.26^{\prime \prime S} / 45^{\circ} 49^{\prime} 22.93 " \mathrm{O}$ \\
\hline São Desidério-BA & BA 8 & $12^{\circ} 17^{\prime} 20.37^{\prime \prime} \mathrm{S} / 45^{\circ} 51^{\prime} 14.56^{\prime \prime O}$ \\
\hline São Desidério-BA & BA 9 & $12^{\circ} 42^{\prime} 54.43^{\prime \prime} \mathrm{S} / 45^{\circ} 45^{\prime} 40.34^{\prime \prime O}$ \\
\hline São Desidério-BA & BA 10 & $12^{\circ} 42^{\prime} 54.43^{\prime \prime} \mathrm{S} / 45^{\circ} 45^{\prime} 40.34^{\prime \prime O}$ \\
\hline São Desidério-BA & BA 11 & $12^{\circ} 42^{\prime} 54.43^{\prime \prime} \mathrm{S} / 45^{\circ} 45^{\prime} 40.34^{\prime \prime O}$ \\
\hline Engenheiro Coelho-SP & $\left(\mathrm{SB}^{*}\right)$ & $22^{\circ} 28^{\prime} 36.43^{\prime \prime} \mathrm{S} / 47^{\circ} 12^{\prime} 56.10^{\prime \prime} \mathrm{O}$ \\
\hline
\end{tabular}

* Susceptible biotype. 
Amaranthus (Sibony et al., 2001; Francischini, 2012).

Doses of trifloxysulfuron-sodium and pyrithiobac-sodium used to obtain a dose response curve, relate to $0,1 / 4,1 / 2,1,2$ and 4 times the recommended dose. Thus, dose 1 (recommended) was set according to work done by Carvalho et al. (2006) and Francischini (2012) for application in pre-emergence in cotton crops.

Although pyrithiobac-sodium was registered for control of $A$. viridis at a dose of $98 \mathrm{~g} \mathrm{ha}^{1}$, the dose equivalent to $140 \mathrm{~g} \mathrm{ha}^{-1}$, was chosen according to work done by Carvalho et al. (2006) and Francischini (2012), to ensure safety margin for making decisions about the resistance of biotypes.

Table 2 shows the doses and herbicides used.

The application was done soon after sowing. At the time of application, the sky was partly cloudy, with a temperature of $26{ }^{\circ} \mathrm{C}, \mathrm{RH} 68 \%$, and wind speed of $1.9 \mathrm{~km} \mathrm{~h}^{-1}$. Immediately after the treatments, the experimental units were irrigated with water depth of $5 \mathrm{~mm}$, and daily irrigation was kept constant until the end of the experiment.

The experimental design was randomized blocks, and each herbicide was considered as a separate experiment. Both experiments were conducted in a factorial $7 \times 6$ scheme, 7 biotypes and 6 doses of each herbicide.

In all experiments, control evaluations were made (visual analogue scale 0-100\%, where $0 \%$ means no symptoms and $100 \%$ total death of weeds) at 28 days after application (DAA), and control values greater than or equal to $80 \%$ were considered to be satisfactory. At 28 DAA, the shoots of the remaining Amaranthus viridis plants were harvested by cutting close to the ground and then placed in paper bags, and placed in an forced air circulation oven at $65{ }^{\circ} \mathrm{C}$ to constant weight. The samples were subsequently weighed for accumulation of dry matter from the experimental units (g per plant). Dry matter was adjusted for percentage values by comparing the weight obtained in the herbicide treatments with the weight of the herbicide-free control, considered as $100 \%$.

The data underwent the application of the F-test in analysis of variance, and they were fitted to the log-logistic, nonlinear regression model for dose-response curves. The control variable was fitted to the model proposed by Streibig et al. (1988):

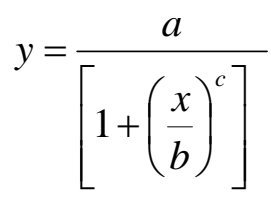

where: $y=$ percentage control; $\mathrm{x}=$ herbicide rate (g a.i. ha ${ }^{-1}$ ); $a, b$ and $c=$ estimated parameters of the equation, where: $a=$ asymptote between the maximum point and the minimum point of the variable; $b=$ rate that provides $50 \%$ of the asymptote; $c=$ slope of the curve around $b$.

From the log-logistic equations, the doseresponse curves were prepared. Based on the fitted models, calculations were made of the herbicide rate, in $\mathrm{g} \mathrm{ha}^{-1}$, that could provide $50 \%$ and $80 \%$ of control $\left(\mathrm{I}_{50}\right.$ and $\left.\mathrm{I}_{80}\right)$. To perform the calculation, the log-logistic model was reversed, as a function of $y$, according to Carvalho et al. (2005):

$$
x=b * \sqrt[c]{\frac{a}{y}-1}
$$

Knowing that the value of $100 \%$ control is not always achieved in dose-response curves, the value of parameter $b$ was disregarded

Table 2 - Herbicides applied in preemergence of weeds and respective doses used for obtaining the dose-response curve of the control of Amaranthus viridis

\begin{tabular}{|l|c|c|c|c|c|c|}
\hline \multirow{2}{*}{\multicolumn{1}{|c|}{ Treatment }} & \multicolumn{7}{c|}{ Doses $\left(\mathrm{g} \mathrm{ha}^{-1}\right)$} & 1 & 2 & 4 \\
\cline { 2 - 8 } & 0 & $1 / 4$ & $1 / 2$ & 7.5 & 15 & 30 \\
\hline Trifloxysulfuron-sodium & 0 & 1.8 & 3.7 & 140 & 280 & 560 \\
\hline Pyrithiobac-sodium & 0 & 35 & 70 & 0.5 & 2 \\
\hline
\end{tabular}


and $\mathrm{I}_{50}$ was calculated by replacing $\mathrm{y}$ in the reverse equation by 50 (control of $50 \%$ of the population). Likewise, replacing y by 80 yields the dose that provides $80 \%$ control $\left(\mathrm{I}_{80}\right)$.

The resistance factor $(\mathrm{RF})$ was calculated by dividing the value of $I_{50}$ of the biotype with suspected resistance by $\mathrm{I}_{50}$ of the susceptible biotype. The resistance factor $(R F=R / S)$ expresses the number of times that the dose required to control $50 \%$ of resistant biotypes is higher than the dose that controls 50\% of susceptible biotypes; biotypes whose values are greater than 1 can be considered as resistant (Christoffoleti, 2002).

In the present work, biotypes were considered resistant when FR $>1.0$ (Christoffoleti, 2002), and two other conditions were met at once: value of $I_{80}$ greater than that of $\mathrm{I}_{80}$ for the susceptible biotype and $\mathrm{I}_{80}$ greater than the dose recommended to control the species.

\section{RESULTS AND DISCUSSION}

\section{Identifying the resistance of Amaranthus viridis to trifloxysulfuron-sodium}

The biotype of $A$. viridis from Mato Grosso do Sul (MS 1) and one of biotypes from Bahia (BA 10) showed a similar response to trifloxysulfuron-sodium compared with the biotype considered as a standard susceptible biotype (SB). It can be seen that, in these cases, the values of $\mathrm{I}_{50}$ and $\mathrm{I}_{80}$ are lower than those obtained for the SB (Table 3). Figures 1B and 1D show reduction of dry matter above $90 \%$ for both biotypes (MS 1 and BA 10) by their exposure to the recommended dose for control of this species $\left(7.5 \mathrm{~g} \mathrm{ha}^{-1}\right)$, a similar behavior observed for the SB.

This suggests that potential failures of control of trifloxysulfuron-sodium associated with this species observed in MS 1 and BA 10 locations may be associated with other factors unrelated to resistance, such as application failures, inadequate doses, plants outside the recommended stage of application or even the incorrect identification of the species.

On the other hand, the Resistance Factor (RF) of some biotypes of $A$. viridis from the State of Bahia was higher than 1.0: BS 11 had
Table 3 - Estimates of parameters a, b and c of the log-logistic model fitted to trifloxysulfuron-sodium, doses for $50 \%\left(\mathrm{I}_{50}\right)$ and $80 \%\left(\mathrm{I}_{80}\right)$ of control of Amaranthus viridis and resistance factor (RF). All the parameters were fitted to the percentage of control at 28 days after application. Maringá, PR - 2011

\begin{tabular}{|l|r|r|c|c|c|r|}
\hline \multicolumn{7}{|c|}{ Trifloxysulfuron -sodium } \\
\hline Locality & \multicolumn{1}{c|}{$\mathrm{a}$} & \multicolumn{1}{c|}{$\mathrm{b}$} & \multicolumn{1}{c|}{$\mathrm{c}$} & $\begin{array}{c}\mathrm{I}_{80} \\
\left(\mathrm{~g} \mathrm{ha}^{-1}\right)\end{array}$ & $\begin{array}{c}\mathrm{I}_{50} \\
\left(\mathrm{~g} \mathrm{ha}^{-1}\right)\end{array}$ & \multicolumn{1}{c|}{$\mathrm{RF}$} \\
\hline MS 1 & 99.92 & 0.00 & -0.58 & 0.20 & $2.00 \mathrm{E}^{-2}$ & 0.77 \\
\hline BA 7 & 83.82 & 1.40 & -1.78 & 7.70 & 1.70 & 66.72 \\
\hline BA 8 & 86.51 & 5.00 & -0.99 & 61.80 & 6.90 & 262.15 \\
\hline BA 9 & 138.18 & 31.20 & -0.61 & 52.50 & 12.30 & 472.39 \\
\hline BA 10 & 109.65 & 0.05 & -1.44 & $3.90 \mathrm{E}^{-2}$ & $1.70 \mathrm{E}^{-2}$ & 0.67 \\
\hline BA 11 & 149.33 & 8.00 & -0.14 & 22.20 & 0.10 & 2.29 \\
\hline SB $^{1 /}$ & 140.13 & 1.00 & -0.16 & 5.80 & $2.60 \mathrm{E}^{-2}$ & 1.00 \\
\hline
\end{tabular}

The coefficients of determination of the log-logistic model $\left(\mathrm{R}^{2}\right)$ ranged between 0.96 and 0.99. ${ }^{1 /} \mathrm{SB}=$ Susceptible Biotype.

relatively low RF (2.29), but BA 7, BA 8 and BA 9 had very high $\mathrm{RF}$, ranging from 66.72 to 472.39 , indicating much higher levels of tolerance to the herbicide than the susceptible biotype. For all biotypes whose $\mathrm{RF}$ was $>1.0, \mathrm{I}_{80}$ was also higher than $\mathrm{I}_{80}$ for the SB. In addition, the doses adjusted to obtain $80 \%$ of control $\left(\mathrm{I}_{80}\right)$ were between 1.3 and 10.7 times higher than those needed to obtain the same level of control of the SB. Therefore, biotypes BA 7, BA 8, BA 9 and BA 11 satisfy all the conditions for being considered as resistant to trifloxysulfuronsodium.

However, there is great variability in the $R F$ values. Relatively low $R F$ values, as observed for BA 11, suggest that the progressive selection of more tolerant biotypes may be occurring. On the other hand, high values as those observed for BA 7, BA 8 and BA 9 biotypes suggest that these biotypes may show complete insensitivity of the ALS enzyme, which could characterize a type of resistance related to change the site of action of herbicide. Similarly, the work developed in Amaranthus tuberculatus by Patzoldt et al. (2005) resulted in high RF values for imidazolinone herbicides (ALS-inhibitors), requiring doses 17 times higher than those used in the susceptible biotype to give 50\% control of the resistant population.

The data suggest that there may be a high genetic variability in populations of $A$. viridis, which imply different levels of susceptibility to trifloxysulfuron-sodium. The analysis of the genetic structure of Euphorbia heterophylla, 

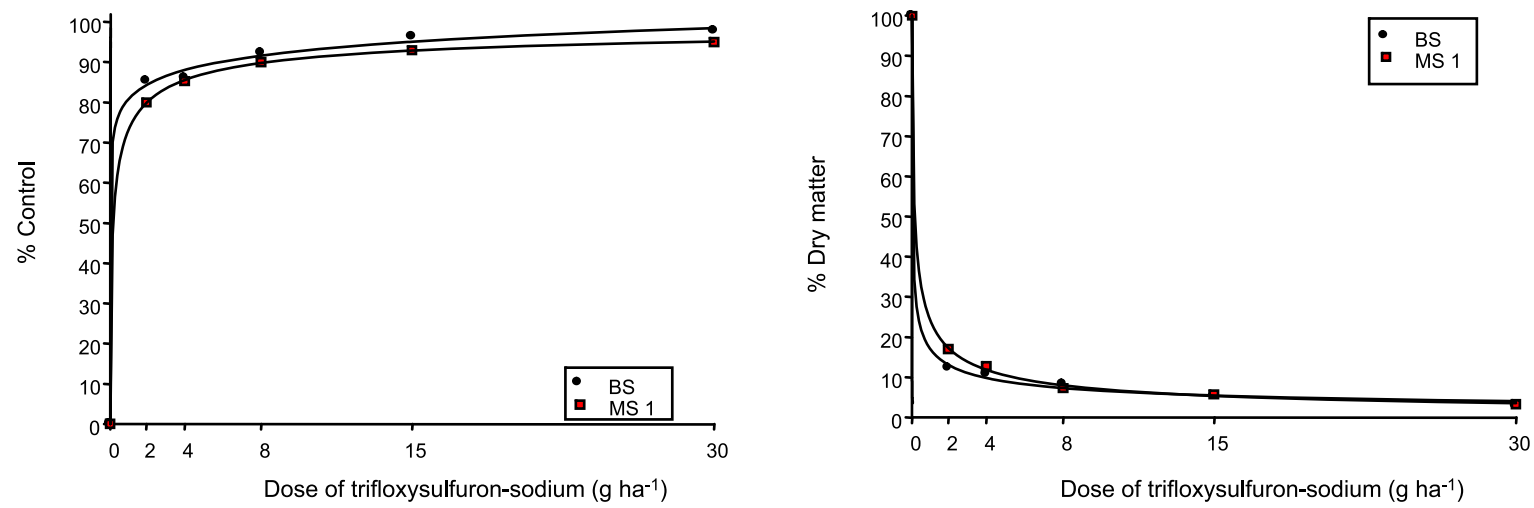

(C)

Bahia

(D)
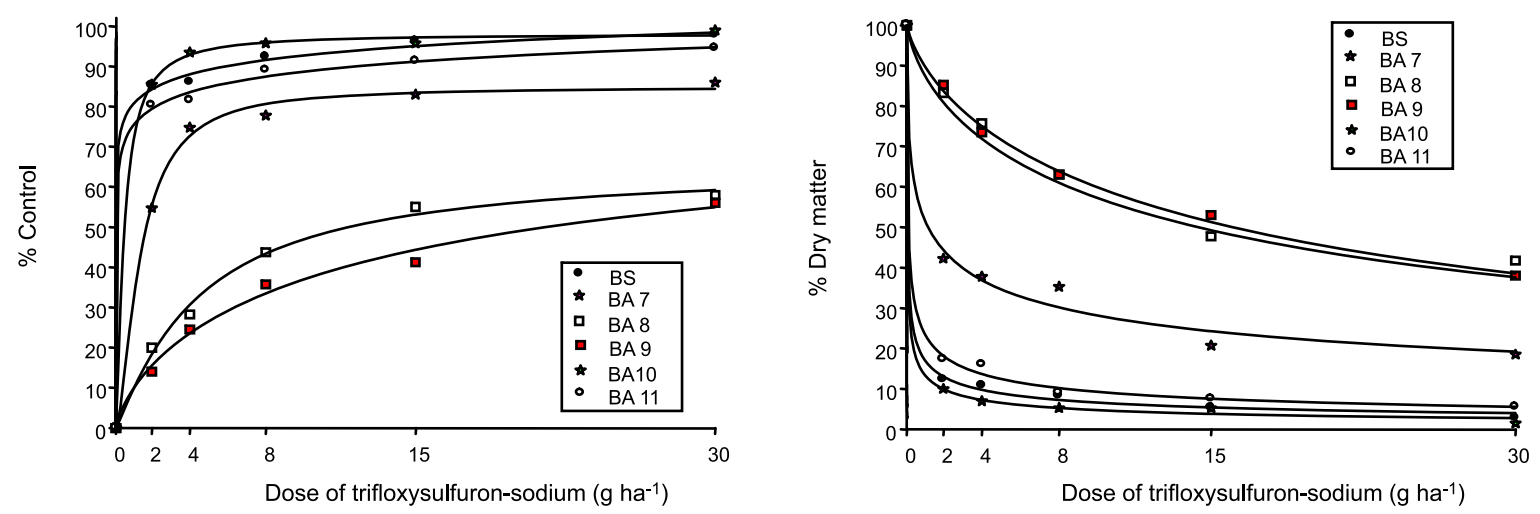

Figure 1 - Dose-response curves of the percentage of control (visual assessment) (left) and relative production of dry matter (\% relative to the zero dose) (right) provided by applying trifloxysulfuron-sodium in control of biotypes Amaranthus viridis from the states of Mato Grosso do Sul (A, B) and Bahia (C, D).

another weed species whose ALS resistant biotypes are found throughout Brazil, indicates that the genetic diversity of these biotypes is correlated with their susceptibility to being selected for resistance to ALS-inhibiting herbicides (Frigo et al., 2009).

The continuous use of trifloxysulfuronsodium by various crops led to the selection of resistant biotypes of $A$. viridis . Further studies are needed to identify the active resistance mechanism in these biotypes.

\section{Identifying the resistance of Amaranthus viridis to pyrithiobac-sodium}

Although three (MS 1, BA 10 e BA 11) out of the six studied biotypes have shown
FR $>1.0$, only MS 1 concomitantly showed higher $\mathrm{I}_{80}$ compared with the SB (Table 4). However, none of the suspected biotypes satisfied the third condition considered in this work to characterize a resistant biotype as, because none of the biotypes from Mato Grosso do Sul and Bahia had $\mathrm{I}_{80}$ greater than the dose considered as the recommended one $\left(1 \mathrm{x}=140 \mathrm{~g}\right.$ ha $\left.{ }^{1}\right)$. The dose considered as the recommended one in this study was estimated from preliminary results (Francischini, 2012), and is at the upper limit of the recommendations proposed by Rodrigues \& Almeida (2011). All biotypes suspected to be resistant showed results for control and dry matter accumulation similar to those of the biotype considered to be susceptible (Figure 2). 
Table 4 - Estimates of the parameters a, b and c of the loglogistic model fitted to pyrithiobac-sodium, doses for $50 \%\left(\mathrm{I}_{50}\right)$ and $80 \%\left(\mathrm{I}_{80}\right)$ control of Amaranthus viridis and resistance factor $(\mathrm{RF})$. All the parameters were fitted to the percentage of control at 28 days after application. Maringá, PR - 2011

\begin{tabular}{|l|r|c|c|r|c|c|}
\hline \multicolumn{7}{|c|}{ Pyrithiobac-sodium } \\
\hline Locality & \multicolumn{1}{|c|}{$\mathrm{a}$} & $\mathrm{b}$ & $\mathrm{c}$ & $\begin{array}{c}\mathrm{I}_{80} \\
\left(\mathrm{~g} \mathrm{ha}^{-1}\right)\end{array}$ & $\begin{array}{c}\mathrm{I}_{50} \\
\left(\mathrm{~g} \mathrm{ha}^{-1}\right)\end{array}$ & $\mathrm{RF}$ \\
\hline MS 1 & 99.95 & 1.20 & -0.37 & 48.60 & 1.20 & 3.92 \\
\hline BA 7 & 104.00 & 0.40 & -0.28 & 25.50 & 0.30 & 0.98 \\
\hline BA 8 & 104.55 & 0.30 & -0.52 & 2.90 & 0.30 & 0.82 \\
\hline BA 9 & 112.80 & 0.30 & -0.67 & 1.10 & 0.20 & 0.69 \\
\hline BA 10 & 102.59 & 0.40 & -0.40 & 8.80 & 0.30 & 1.15 \\
\hline BA 11 & 101.90 & 0.40 & -0.42 & 8.70 & 0.30 & 1.19 \\
\hline SB $^{1 /}$ & 107.21 & 0.05 & -0.27 & 25.10 & 0.30 & 1.00 \\
\hline
\end{tabular}

The coefficients of determination of the log-logistic model $\left(\mathrm{R}^{2}\right)$ ranged between 0.96 and $0.99 .{ }^{1 /} \mathrm{SB}=$ Susceptible biotype.

Once, the samples of the biotypes from locations MS 1, BA 7, BA 8, BA 9, BA 10 and BA 11 were not considered to be resistant to the herbicide pyrithiobac-sodium. Possible failures in control observed after application of the herbicide may be associated with other factors not related to resistance.

Although trifloxysulfuron-sodium and pyrithiobac-sodium have the same mechanism of action (inhibition of the ALS enzyme), they belong to different chemical groups: the former belongs to the chemical group of the sulfonylureas and the latter, to the chemical group of pyrimidinylthiobenzoates. Although there is no history of the sampled localities with enough details to show the number of times that each of these herbicides was used, the intensity is similar in terms of number of applications. This suggests that the biotypes may show differential response in terms of susceptibility to different ALS-inhibiting chemical groups.

To date, 142 cases of resistance to ALS inhibitors have been identified; however, only 16 cases out of them are associated with pyrithiobac-sodium and 7 of them with trifloxysulfuron-sodium (Heap, 2014). Many of the cases of resistance to these herbicides are associated with other species of the same genus, Amaranthus palmeri.

It is known that there are several trigger mechanisms of resistance to ALS-inhibiting herbicides, and that most cases of resistance identified to date result from mutations in the ALS enzyme. Whaley et al. (2007) showed on analysis at the molecular level of Amaranthus that resistance to ALS-inhibiting herbicides occurred due to simple substitutions at the position of specific amino acids, which provided different rates of resistance.

The difference in resistance for the two chemical groups may be due to the limited number of herbicides available in the market as regards pyrimidinylthiobenzoates (only two), or it may be associated with specific mutations in ALS that may result in resistance to certain chemical groups.

Molecular studies conducted by Duggle \& Pang (2000) showed 17 different amino acid substitutions in the DNA sequence of the ALS enzyme capable of making plants, bacteria, green algae, and yeast resistant to ALS inhibitors. However, Powles \& Yu (2010) reported that only seven of these substitutions in the ALS enzyme are responsible for causing resistance in plants, Ala122, Pro197, Ala205, Asp376, Trp574, Ser653 and Gly654.

The resistance to various herbicides of same mechanism of action (known as cross-resistance) depends on the position of substitution of specific amino acids and on the particular substitution (Shaner, 1999). Thus, substitutions at position $\mathrm{Ala}_{122}$ or $\mathrm{Ser}_{653}$ give little or no resistance to herbicides of the sulphonylurea group, and a high rate of resistance to herbicides of the imidazolinone group (Bernasconi et al., 1995; Devine \& Eberlein, 1997; Patzoldt \& Tranel, 2007). Likewise, substitutions at $\mathrm{Pro}_{197}$ give resistance to sulfonylureas (Guttieri et al., 1992), but little or no resistance to the imidazolinone group. Substitutions at $\operatorname{Trp}_{574}$ or $\mathrm{Ala}_{205}$ provide resistance to the four chemical groups belonging to ALS inhibitors (sulfonylureas, triazolopyrimidines, imidazolinones and pyrimidinylthiobenzoates).

It is possible that resistance to trifloxysulfuron-sodium observed in some biotypes of $A$. viridis in the present study may be related to some specific amino acid substitutions for the ALS enzyme or related to other factors not considered, such as a greater ability to metabolize, compartmentalization or limited translocation to the site of action. 
(A)

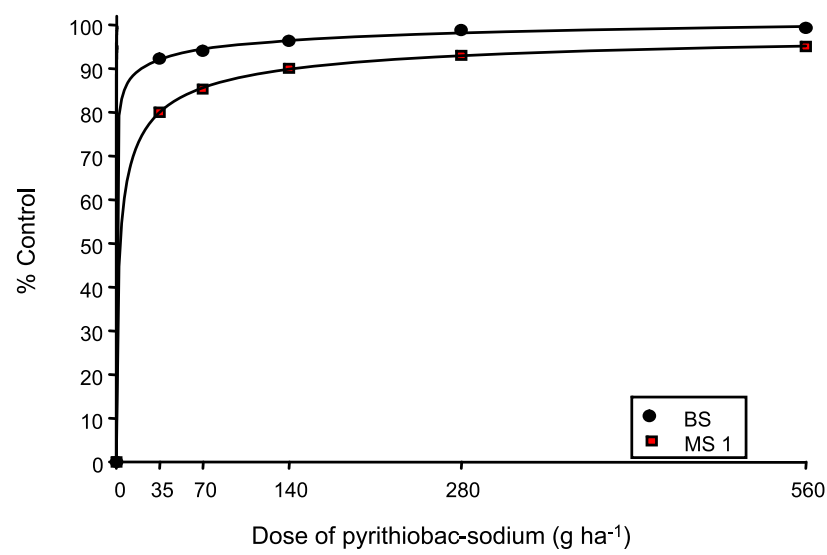

(C)

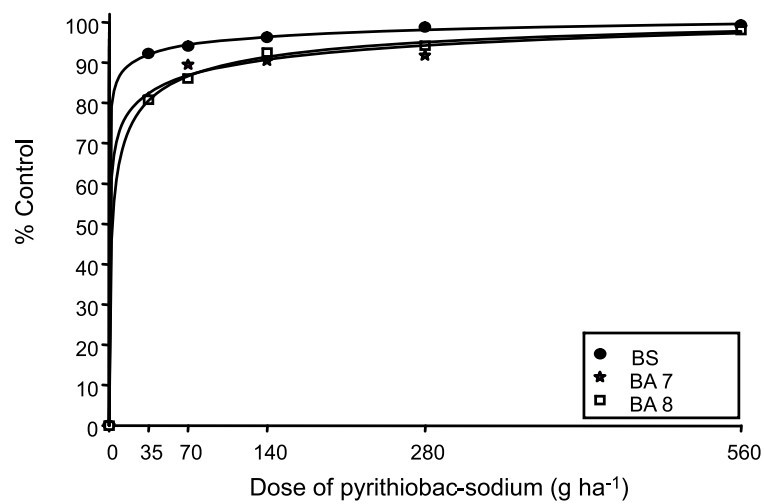

(E)

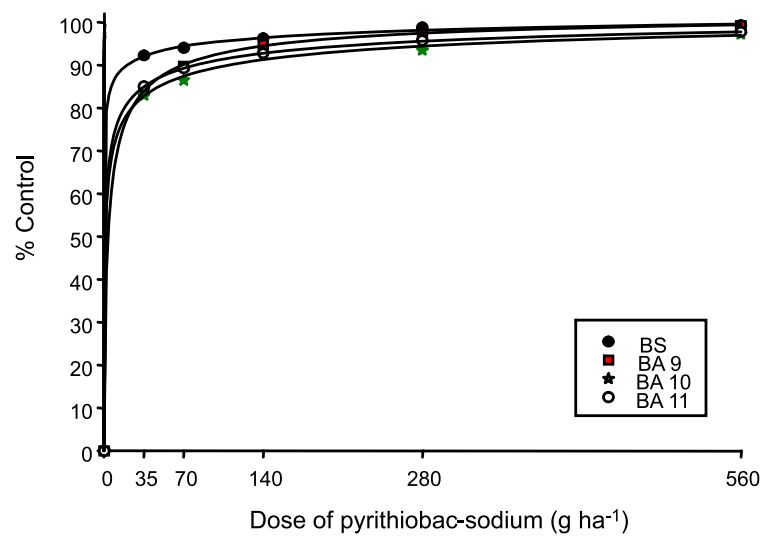

Mato Grosso do Sul

(B)

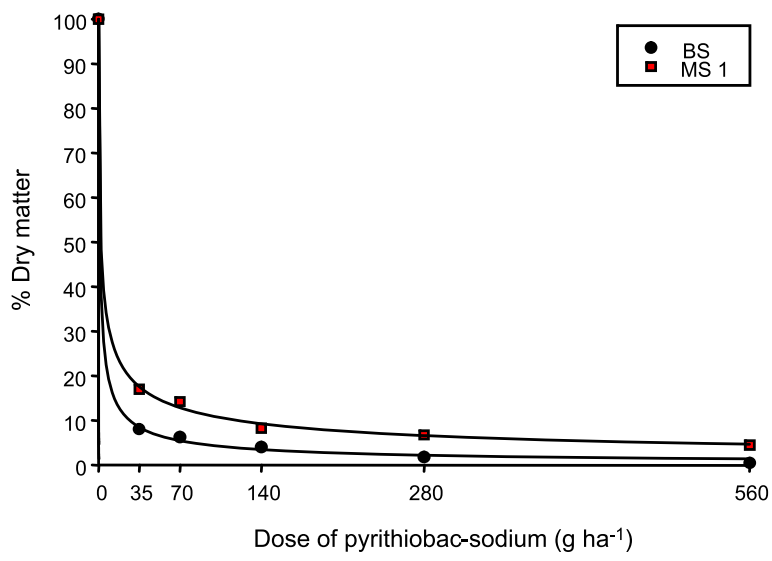

Bahia

(D)

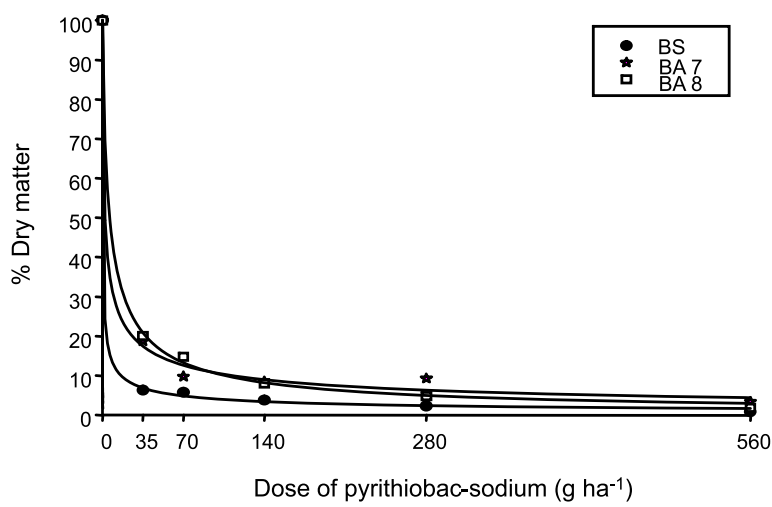

Bahia

(F)

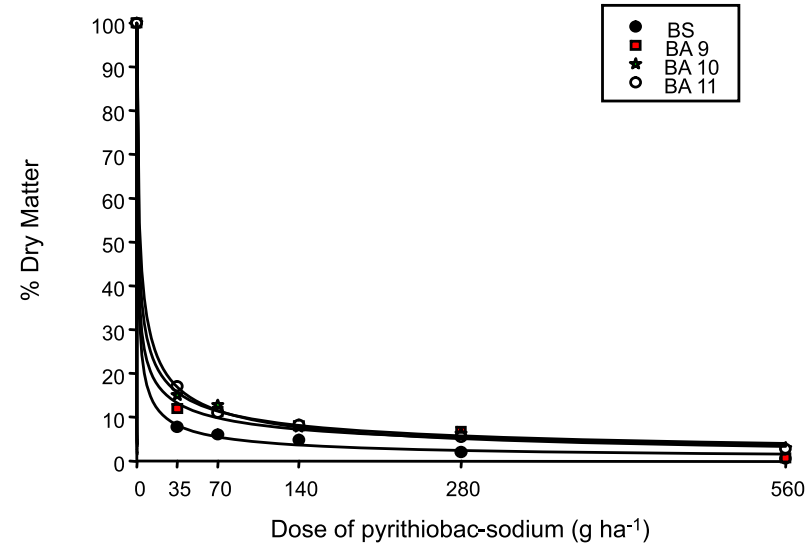

Figure 2 - Dose-response curves of the percentage of control (visual assessment) (left) and relative production of dry matter (\% relative to the zero dose) (right) provided by applying pyrithiobac-sodium in control of biotypes Amaranthus viridis from the states of Mato Grosso do Sul (A, B) and Bahia (C, D, E, F). 
To elucidate the mechanisms of resistance associated with these biotypes, further research is needed at the physiological and metabolic level.

Thus, the resistance of Amaranthus viridis biotypes collected from the state of Bahia can be confirmed to trifloxysulfuron-sodium only, thus not characterizing any kind of crossresistance. This paper describes the first case of resistance of Amaranthus viridis to herbicides in Brazil and worldwide.

\section{LITERATURE CITED}

BERNASCONI, P. et al. A naturally occurring point mutation confers broad range tolerance to herbicides that target acetolactate synthase. J. Biol. Chem., v. 270, n. 29, p. 17381-17385, 1995.

CARVALHO, S. J. P. et al. Curvas de dose-resposta para avaliação do controle de fluxos de emergência de plantas daninhas pelo herbicida imazapic. Planta Daninha, v. 23, n. 3, p. 535-542, 2005.

CARVALHO, S. J. P. et al. Susceptibilidade diferencial de plantas daninhas do gênero Amaranthus aos herbicidas trifloxysulfuron-sodium e chlorimuron-ethyl.

Planta Daninha, v. 24, n. 3, p. 541-548, 2006.

CHRISTOFFOLETI, P. J. Curvas de dose-resposta de biótipos resistente e susceptível de Bidens pilosa L. aos herbicidas inibidores da ALS. Sci. Agric., v. 59, n. 3, p. 513-519, 2002.

DEVINE, M. D.; EBERLEIN, C. V. Physiological, biochemical e molecular aspects of herbicide resistance based on altered target sites. In: ROE, R. M.; BURTON, J. D.; KUHR, R. J. Toxicology, biochemistry and molecular biology of herbicide activity. Amsterdam: IOS Press, 1997. p. 159-185.

DUGGLEBY, R. G.; PANG, S. S. Acetohydroxyacid synthase. J. Biochem. Molec. Biol., v. 33, n. 1, p. 1-36, 2000.

FRANCISCHINI, A. C. Identificação de resistência aos herbicidas utilizados no algodoeiro em biótipos de Amaranthus retroflexus e Amaranthus viridis oriundos das regiões produtoras da Bahia, Goiás, Mato Grosso e Mato Grosso do Sul. 2012. 141 f. Dissertação (Mestrado em Agronomia, área de concentração Proteção de Plantas) Universidade Estadual de Maringá, Maringá, 2012.

FRIGO, M. et al. Esterase polymorphism for analysis of genetic diversity and structure of wild poinsettia (Euphorbia heterophylla) populations. Weed Sci., v. 57, n. 1, p. 54-60, 2009.

GUTTIERI, M. J. et al. DNA sequence variation in domain A of the acetolactate synthase genes of herbicide resistant and susceptible weed biotypes. Weed Sci., v. 40, n. 3, p. 670676, 1992.
HEAP, I. The International Survey of Herbicide Resistant Weeds. Online Internet. Saturday, January 25, 2014. Available: <www.weedscience.com>.

LORENZI, H.; MATOS, F. J. A. Plantas medicinais no Brasil: nativas e exóticas. Nova Odessa: Plantarum, 2002. 512 p.

MALUF, A. M. Competição intraespecífica entre Amaranthus hybridus L. e Amaranthus viridis L. Pesq. Agropec. Bras., v. 34, n. 1, p. 1319-1325, 1999.

PATZOLDT, W. L.; TRANEL, P. J. Multiple ALS mutations confer herbicide resistance in waterhemp (Amaranthus tuberculatus). Weed Sci., v. 55, n. 5, p. 421-428, 2007.

PATZOLDT, W. L. et al. A waterhemp (Amaranthus tuberculatus) biotype with multiple resistance across three herbicide sites of action. Weed Sci., v. 5, n. 1, p. 30-36, 2005.

POWLES, S. B.; YU, Q. Evolution in action: plants resistant to herbicides. Annual Rev. Plant Biol., v. 61, n. 1, p. 317-347, 2010.

RAIMONDI, M. A. et al. Atividade residual de herbicidas aplicados ao solo em relação ao controle de quatro espécies de Amaranthus. Planta Daninha, v. 28, p.1073-1085, 2010. (Número Especial)

RODRIGUES, B. N.; ALMEIDA, F. S. Guia de herbicidas. Londrina: Edição dos Autores, 2011. 697 p.

SHANER, D. L. Resistance to acetolactate synthase (ALS) inhibitors in the United States: history, occurrence, detection, e management. Weed Res., v. 44, n. 1. p. 405-411, 1999.

SIBONY, M. et al. Sulfometuron-resistant Amaranthus retroflexus: cross-resistance e molecular basis for resistance to acetolactate synthase-inhibiting herbicides. Weed Res., v. 41, n. 1, p. 509-522, 2001.

STREIBIG, J. Herbicide bioassay. Weed Res., v. 28, n. 1, p. 479-484, 1988.

WHALEY, C. M. et al. A new mutation in plant ALS confers resistance to five classes of ALS-inhibiting herbicides.

Weed Sci., v. 55, n. 2, p. 83-90, 2007.

WISE, A. M. et al. Establishing the geographical distribution and level of acetolactate synthase resistance in Palmer amaranth (Amaranthus palmeri) accessions in Georgia. Weed Technol., v. 23, n. 1, p. 200-214, 2009.

VIANA, V. R. C. Contribuição ao estudo anatômico do eixo vegetativo de Amaranthus viridis $L$.

(Amaranthaceae). 1982. 92 f. Dissertação (Mestrado em Botânica) - Universidade Federal do Rio de Janeiro, Rio de Janeiro, 1982. 